\title{
The Analysis of the Foreign Exchange Reserves Growth in China
}

\author{
Heyan Zhou \\ School of Earth Sciences and Engineering, Nanjing University, Nanjing 210046, China \\ heyan.z.x@gmail.com
}

\begin{abstract}
In recent years, owing to the international balance of payments surplus, direct investment and net capital inflows, the scale of China's foreign exchange reserves is becoming larger and larger. In this paper, based on the analysis of the structure of the source of foreign exchange reserves in China and the status quo of China's foreign exchange reserves growth, the reason of the growth of FER is analyzed, and it gives a theoretical and practical significance to the healthy development of China's national economy.
\end{abstract}

Keywords: Foreign exchange reserves; Foreign investment; External trade.

\section{Introduction}

The rapid growth of China's foreign exchange reserves has become a hot topic for research in recent years. The foreign exchange reserves in China have been greatly increasing since the structural reform of foreign exchanges was carried out when the market economy system was established in 1994 [1]. The foreign exchange reserves of China exceeded that of Japan in size for the first time in 2006, and have ranked the first in the whole world ever since. The main reason for the dramatic growth of foreign exchange reserves lies in the export-led economic structure, processing trade, and drastic inflow of foreign direct investment by incentive policies [2]. Proper amount of foreign exchange reserves (FER) is of significance for the stability of macro-economy and for the prevention of financial crisis [3]. Nonetheless, in the context of global crisis \& global economic imbalance, China's foreign exchange reserves face a huge risk of shrinkage. With the continuous enhancement of foreign exchange reserves, its negative effects keep popping up: huge loss of domestic resources, lack of innovation dynamism, trade frictions, and sustained domestic inflation. Therefore, the study on the structure and scale of China's foreign exchange reserves is significant to promotion of innovation-driven strategy and relieve the negative effects of foreign exchange reserves.

\section{The features and functions of foreign exchange reserves}

The foreign exchange reserves (FER) refers to the part of foreign exchange in the International reserve assets hold by a country's government. It is stored as international monetary, held by the monetary authorities of the country and can be converted into foreign currency assets at any time[4].

\subsection{The features of foreign exchange reserves}

The features of FER can be summarized as follows:

1) The administrator and holder of FER must be the monetary authorities. It is means that the foreign exchange holds by folk and other official bodies doesn't belong to FER. 2) The FER can be used at any time. It has mobility and changeability. 3) The FER is directly and effectively controlled by monetary authorities. Once the FER is sold by the central bank, whether the buyers are a commercial bank or government, it is no longer belong to the foreign exchange reserves. 4) The external assets used as the FER is the creditor's rights of monetary authorities to the non-resident. 5) The long-term foreign exchange loan to non-residents by monetary authorities isn't foreign exchange reserves. While the short term foreign exchange loan which can be used at any time can be as the FER. In China, the definition of FER is technically in accordance with the above, mainly hold and manage the People's Bank of China.

\subsection{The functions of foreign exchange reserves}

The functions of FER can be summarized as follows. 
1) The FER can adjust the international balance of payments and guarantee the external payments. When the balance of international payments temporarily deficit, foreign exchange reserves can be used to cover. While the deficit is long-term and fundamental, the foreign exchange reserves also can be used as cushion to release the negative effects of the regulation.

2) The FER can intervene in currency markets and stable the exchange rates. When the market is rapid fluctuation in short term, government can adjust the exchange rate through buying and selling foreign exchange reserves.

3) The FER can be used as credit guarantee. One country's FER is the important guarantee of borrowing and debt servicing. Plenty of foreign exchange reserves suggests that a country has a good solvent, which can make it easily to obtain all kinds of loans in the international market for financing.

4) The FER can be used to deal with the emergency payment caused by all kinds of emergencies. Economic globalization has greatly enhanced the connection between the world's economies, while at the same time expanding the country's economic and financial risks. In this circumstances, having plenty of reserves can relieve the impact produced by international economic and financial crisis.

5) The FER also can be used as a macroeconomic regulation and control tools to promote the healthy development of national economy. According to the domestic economy to effectively manage the foreign exchange reserves can maintain the stability of interest rate and exchange rate in short terms, and protect relatively independent of monetary policy.

\section{The structure analysis of the source of foreign exchange reserves}

The source of foreign exchange reserve can be divided into two parts according to the nature of the source of FER. The FER is mainly come from the balance of payments surplus, according to the nature of the sources, FER can be divided as the FER form the creditor's rights and the FER from the debt.

\subsection{The FER from the creditor's rights}

The FER from the creditor's rights is mainly caused by the surplus of current account. Current account includes trade in goods, trade in services, investment income, and current transfer project, and usually represent the trade and exchanges of realistic resources between countries. The FER earnings obtained from this part is independence and can be controlled by governments, which has no need to concern the problem of payback in the future. The FER from the creditor's rights caused by the surplus of current account is the main part of a country's FER, the surplus country has the right to use and own the FER.

In China, according to the data of the balance of payment in China during 1994-2012, the payment of the current account from 1994 to 2012 is always the trade surplus and the goods trade surplus is the main cause of the current account surplus. The goods trade surplus consists about $80 \%$ of the surplus of current account, which can make up the current-account deficit from other projects. The services trade balance is mostly the trade deficit except in 1994 during of which has small amount of surplus. The investment income account balance is mostly the trade deficit except a few years' surplus. The projects of service trade and investment are the consumption of the source of foreign exchange reserves. According to the balance of payment data from nearly 19 years, the goods trade surplus is the main reason of the current account surplus, and also the main source of the foreign exchange reserves in China.

\subsection{The FER from the debt}

The FER from the debt is mainly caused by the capital and financial account surplus. The capital and financial subjects includes unilateral capital transfer, direct investment, securities investment and other investment projects. Compared to the current account, the frequency trade of financial and capital account is not as high as current account, and the trade often involves the pure cash flow, the amount of money is relatively larger. However, the FER from the debt could have the possibilities of capital withdrawal or profit repatriation in the future, so it is not a country's stable foreign exchange reserves. 
In China, according to the data of the balance of international payments from 1994 to 2012, the trade balance of capital and financial account is mostly the trade surplus except the year in 1998. And the trade surplus from the direct investment accounted for more than 50\% of the capital and financial account surplus. Therefore, the direct investment surplus is the main cause to the capital and financial account surplus. The unilateral transfer capital projects, the securities investment projects and other projects have a certain influence on the net capital and financial account, but not that significant.

According to the analysis above, it can be summarized that on one hand, the current account surplus and the capital and financial account surplus is the main sources of China's FER. On the other hand, the exchange rate targets under the restriction of employment makes the Chinese foreign exchange reserve passively increasing for a long time which leads to the pressure of appreciation of the RMB.

\section{The status quo of China's foreign exchange reserves growth}

\subsection{The growth of China's total foreign exchange reserves}

After China's foreign exchange management system reform in 1994, the trades to the other countries becomes more and more frequency. Under the influence of the balance of payments surplus, the foreign direct investment and the inflows of the international hot money, China's FER increases sharply. In 2002, China's foreign exchange reserves is $\$ 286.407$ billion, overtake Japan as the world's largest current account and capital account surplus country. After the reform in July 2005, China's foreign exchange reserve scale opened up a new round of rapid growth, overtake Japan became the world's largest foreign exchange reserves country in 2006. By the end of 2012, the total of China's foreign exchange reserves was increased to $\$ 3.31$ trillion, ranked first in the world for seven consecutive years. The FER account for about $85.6 \%$ of total volume of foreign trade which means China's foreign exchange reserves is quite enough.

From the perspective of the changes of China's foreign exchange reserves, The Chinese foreign exchange reserve may have had from the shortage stage (1979-1979) to adequate stage (1994-1994), to the rapid growth or even excess reserves in recent years. In recent years, China has basically realized the change from the balance of payments continued large double surplus pattern before the international financial crisis in 2007 to the relatively small double surplus. On one hand, it is due to the appreciation of the RMB; on the other hand, it also has the impact of international economic rebalancing. In general, with the further development of China's economy and the increasing of the strength of opening outside, China will continue to keep the double surplus of the current and capital accounts, and the scale of FER will keep growing in the long run.

\subsection{The features of China's foreign exchange reserves growth}

After China's foreign exchange management system reform, under the influence of the balance of payments surplus, the foreign direct investment and the inflows of the international hot money, China's FER increases sharply. Especially in recent years, the FER of China shows a supernormal growth trend. Specifically, the growth of China's foreign exchange reserves mainly has the following significant features.

1) The scale of FER growth rapidly, from 2001 to 2012, China's foreign exchange reserves increased by 15 times;

2) The scale of foreign exchange reserve is too big, the proportion of the total share of global foreign-exchange reserves is $30.4 \%$ in 2011, \$ 2000 trillion higher than Japan;

3) The scale of China's foreign exchange reserve is more than a reasonable level, according to the Triffin proportion method, a country's foreign exchange reserves should be the proper proportion of imports, the optimal standard should be $40 \%$, while China's FER is $85.6 \%$ of total volume of foreign trade in 2012, the scale of FER is obviously excessive. 


\section{The reason of the rapid growth of China's foreign exchange reserves}

\subsection{The rapid development of the national economy is the economic base}

As one of the important economic variables, the rapid growth of FER is the outcome of the accumulation of China's social economic productivity, foreign economic development and comprehensive strength. The growth of China's FER is positively correlated with macro-economic development. The rapid growth of national economy and the powerful economic strength of China have laid a solid material foundation of the growth of the FER of China.

\subsection{The long-term double surplus of current and capital account is the direct cause}

Based on the structure analysis of the source of foreign exchange reserves in China, it is obvious that the main power of the growth of China's FER come from the current and capital account surplus, it is the direct cause of the long-term double surplus. Under the forced out system, this kind of long-term double surplus will undoubtedly cause of the excessive growth of China's foreign exchange reserves.

\subsection{The increasing of China's increasing foreign debt balance is objective cause}

Since China executes the reform and opening-up policy, the total external debt balance is keeping the trend of increasing, average annual growth is about 23\%. Among them, the medium and long-term foreign debt balance increased from $\$ 9.41$ billion in 1985 to $\$ 194.1$ billion at the end of 2011, up nearly 20 times; so as the balance of short-term foreign debts which increased from $\$ 642$ million in 1985 to $\$ 500.9$ billion in the end of 2011, average annual growth rate is as high as $33.57 \%$. So the increasing of China's increasing foreign debt balance is the objective cause of the FER.

\subsection{The improve of the financial system in China encourage the inflows of foreign capital}

As for the current development situation of the financial market in China, on one hand, China has established a relatively healthy financial system, especially the foreign exchange market the function of which is gradually complete, provides organization guarantee for the foreign capital inflows [5]; on the other hand, China's financial opening and a series of structure reform create a looser system environment for foreign capital inflows and outflows.

\section{Conclusion}

Under the influence of the balance of payments surplus, foreign direct investment inflows and the international hot money inflows, China's FER has growth rapidly in recent years. Based on the analysis of the structure of the source of foreign exchange reserves in China and the status quo of China's foreign exchange reserves growth, the analyze of the reason of the growth of FER is very important to the management and well use of the huge foreign exchange reserves, and has theoretical and practical significance. There are many reasons for the rapid growth of China's FER, in order to maintain reasonable growth in foreign exchange reserves in China, the government should focus on the fluctuation of RMB exchange rate, in case the volatility caused by other macroeconomic factors, to maintain the healthy development of China's economy.

\section{References}

[1] Gupta, R., et al., Forecasting China's foreign exchange reserves using dynamic model averaging: The roles of macroeconomic fundamentals, financial stress and economic uncertainty. North American Journal of Economics \& Finance, 2014. 28(C): p. 170-189.

[2] Wang, Y., X. Hui, and A.S. Soofi, Estimating renminbi (RMB) equilibrium exchange rate. Journal of Policy Modeling, 2007. 29(3): p. 417-429.

[3] Mathews, J.A., Dragon multinationals: New players in 21st century globalization. Asia Pacific Journal of Management, 2006. 23(1): p. 5-27.

[4] Dooley, M.P., an Analysis of the Management of the Currency Composition of Reserve Assets and External Liabilities of Developing Countries. 1987: Palgrave Macmillan UK.

[5] Glick, R. and M. Hutchison, Navigating the trireme: Capital flows and monetary policy in China. Journal of Asian Economics, 2009. 20(3): p. 205-224. 